\title{
Committees
}

\section{EXEGUTIVE COMMITTEE}

\author{
D I R E G T O R
}

Rudolph E. Habenicht Simon Fraser University

EXEGUTIVE SEGRETARY

J.A. Lavin University of British Columbia

M E M B E R S

David Galloway University of New Brunswick

Berners Jackson McMaster University

Glifford Leech University of Toronto

Trevor Lennam University of Calgary

Paul J. Marcotte Université d'Ottawa

Gerald Newman Simon Fraser University

D.F. Rowan University of New Brunswick

C O N S U L T A N T

R.W. Ingram University of British Columbia

INTERNATIONAL ADVISORY GOMMITTEE

E U R O P E

Peter Alexander $\dagger$

Alexander Anikst Institute of the History of the Arts, Moscow

Gabriele Baldini $\dagger$

Wolfgang Clemen University of Munich

Sir John Gielgud London, England

Elemér Hankiss Institute of Literary History of the Hungarian Academy of Sciences

Stanisław Helstzynski Neophilological Committee of the Polish Academy of Sciences

Jean Jacquot Centre national de la recherche scientifique, Paris

G. Wilson Knight Exeter, England

John Lawlor University of Keele

Martin Lenhert Humboldt University, Berlin 
Agostino Lombardo University of Rome

Salvador de Madariago Exeter College, Oxford

Marco Mincoff University of Sofia

Allardyce Nicholl Malvern, England

Mario Praz University of Rome

Kristian Smidt British Institute, University of Oslo

T.J.B. Spencer The Shakespeare Institute, University of Birmingham

Zdeněk Stříbrný Charles University, Prague

Glynne Wickham University of Bristol

NORTH A N D SO U T H A M E R C A

Fredson Bowers University of Virginia

Madeleine Doran University of Wisconsin

Sidney T. Fisher Montreal

Jean Gascon Stratford, Ontario

Alfred Harbage Harvard University

O.B. Hardison, Jr The Folger Shakespeare Library

Richard Hosley University of Arizona

James G. McManaway Washington $D C$

Arturo Tienken University of Conçepción, Chile

Louis B. Wright Washington $D C$

A F R I C A

Eldred Jones University of Sierra Leone

A S I A

Toshikazu Oyama Seijo University, Tokyo

S.C. Sen Gupta Jadaupur University, India

A U S T R A L A S I A

S. Musgrove University of Auckland

H.J. Oliver University of New South Wales 
SHAKESPEARE 1971 
